\title{
РЕЙТИНГ АГРАРНЫХ ВУЗОВ КАК ИНСТРУМЕНТ УПРАВЛЕНИЯ РАЗВИТИЕМ АГРАРНОГО ОБРАЗОВАНИЯ В РОССИИ
}

\author{
(c) 2020 Ларина Татьяна Николаевна \\ доктор экономических наук, доцент, \\ профессор кафедры экономики АПК и экономической безопасности \\ Оренбургский государственный аграрный университет, Россия, Оренбург \\ E-mail: lartn.oren@mail.ru \\ (c) 2020 Маловский Николай Анатольевич \\ кандидат технических наук, доцент, советник при ректорате \\ Оренбургский государственный аграрный университет, Россия, Оренбург \\ E-mail: malovskiy@list.ru \\ (c) 2020 Шахов Владимир Александрович \\ доктор технических наук, профессор, \\ начальник управления по организации научных исследований и подготовке научных кадров \\ Оренбургский государственный аграрный университет, Россия, Оренбург \\ E-mail: shahov-v@yandex.ru
}

Авторы статьи проанализировали рейтинг аграрных вузов России, проводимый Департаментом научно-технической политики и образования Министерства сельского хозяйства Российской Федерации за 2018-2019 гг. Выделены лидирующие университеты по направлениям «образовательная деятельность» и «научно-исследовательская деятельность», проблемы в современной системе аграрного образования России.

Ключевые слова: рейтинг, аграрные вузы, проблемы, инструмент управления, аграрное образование, анализ, группировка, развитие.

Введение. Обеспечение продовольственной безопасности страны на основе развития отечественного сельского хозяйства и производств по переработке сельскохозяйственного сырья, достижение стратегических целей по увеличению экспорта продукции АПК невозможны без профессиональных кадров, способных адаптироваться к требованиям научно-технического прогресса. В Федеральной научно-технической программе развития сельского хозяйства на 2017-2025 годы, утвержденной Правительством Российской Федерации в августе 2017 г. [3], которая предназначена решить перечисленные задачи, уделяется внимание также аграрному образованию и науке. В России подготовку по специальностям и направлениям образовательных программ аграрного профиля осуществляют 54 учреждения высшего образования, подведомственных Министерству сельского хозяйства Российской Федерации.

В целях формирования информационноаналитических материалов, отражающих состояние высшего аграрного образования, в
Минсельхозе России с 2016 г. проводится внутриведомственный мониторинг. В 2018 г. уточнена программа мониторинга, утвержден порядок формирования рейтинга вузов. В настоящее время результатом мониторинга является формирование ранжированного списка образовательных организаций, построенного на основе рейтинговых оценок показателей аграрных вузов. Данный рейтинг позволяет оценить текущее состояние и эффективность деятельности вузов, сравнить их достижения и выделить лидеров в сфере аграрного образования и науки. Главная задача мониторинга - получить целостное представление о развитии системы аграрного образования, что напрямую связано с достижением общегосударственных целей по развитию АПК страны.

Построение рейтингов учебных заведений высшего образования применяется в отечественной и мировой практике на протяжении многих лет. В частности, широко известны такие рейтинги ведущих университетов мира, как World University Rankings (Times Higher Education), 
Academic Ranking of World Universities (болеe известный в России как Шанхайский рейтинг), U-Multirank (разработка которого была инициирована Европейской комиссией ЕС), рейтинг лучших университетов развивающихся стран Европы и Центральной Азии, публикуемый британской компанией Quacquarelli Symonds (QS) и др. [2] Министерство науки и высшего образования Российской Федерации ежегодно проводит оценку эффективности деятельности подведомственных бюджетных и автономных образовательных учреждений высшей школы по четырем группам показателей (качество образования, международная деятельность, научная деятельность, финансовая деятельность) [4]. Российская компания ООО «РАЭКС-Аналитика» формирует рейтинг вузов страны, определяя первую сотню высших учебных заведений по показателям их образовательной, научно-исследовательской деятельности, учитывая мнение работодателей, представителей академических и научных кругов, студентов, выпускников [5].

Аграрные вузы России, к сожалению, пока не могут массово конкурировать на международном образовательном поле. В 2018 г. впервые в число трехсот лучших вузов развивающихся стран Европы и Центральной Азии, согласно рейтингу QS, вошел РГАУ-МСХА им. К.А.Тимирязева, заняв 201-250 позиции [6]. Внутри страны отдельные аграрные вузы вполне могут соперничать с ведущими отечественными университетами. Так, по итогам 2019 г. в топ-100 российских вузов, по оценке РАЭКС, вошли СтавропольскиЙ ГАУ (60 место) и РГАУ-МСХА им. К. А. Тимирязева (62 место) [5].

Учитывая специфику аграрного образования в нашей стране, построение рейтинга аграрных вузов Министерством сельского хозяйства РФ вполне оправдано. По мнению многих представителей системы образования, формирование и критический анализ рейтингов позволит, в том числе, укрепить связи между научнообразовательным сообществом и производством, укрепить кадровый потенциал АПК в условиях цифровизации экономики [1].

Методология и методы исследования. В июне 2020 г. была утверждена последняя на сегодняшний день версия Порядка формирования рейтинга образовательных организаций высшего образования Министерства сельского хозяйства Российской Федерации. Согласно документу, оценка эффективности деятельности аграрных вузов проводится по 7 направлениям. Каждое направление характеризуется соответствующими показателями (всего 46 показателей): образовательная деятельность (ОД) (9 показателей); научно-исследовательская деятельность (НИД) (14 показателей); международная деятельность (МД) (3 показателя); финансово-хозяйственная деятельность (ФХД) (8 показателей); воспитательная работа (ВР) (3 показателя); отраслевые показатели (ОП) (6 показателей); дополнительные показатели (ДП) (3 показателя).

Судя по наполнению блоков исходных показателей, наиболее значимыми являются показатели по образовательной и научноисследовательской деятельности. Именно эти критерии дают возможность внешним пользователям получить представление о вузе в его базовом понимании - как о месте, где учат «зарабатывать на хлеб» профессионалы высокого уровня. Создав определенную научную и учебную инфраструктуру, университет в дальнейшем может более успешно привлекать внешнее финансирование, поднять престиж вуза среди абитуриентов и т.п. Блок «финансовохозяйственная деятельность» включает 8 показателей, что также демонстрирует значимость фактора финансовой устойчивости организации, наряду с научной и образовательной деятельностью вуза. Остальные блоки дополняют картину, позволяют учесть специфику аграрных вузов.

Необходимо отметить, что в мировой практике формирования рейтинговых оценок университетов применяются аналогичные подходы, схожий набор показателей. В частности, рассматриваются количество и цитируемость публикаций преподавателей, доходы университета, интернационализация, получение престижных международных премий, успеваемость студентов, репутация и другие [9]. Вместе с тем, научное сообщество постоянно критически обсуждает международные рейтинги университетов за порой избыточное внимание к публикационной активности преподавателей, что может снизить качество подготовки студентов, а также за спорные весовые коэффициенты для тех или иных показателей, включаемых в итоговый рейтинг [7]. Очевидно, международные рейтинги университетов являются в большей мере элементом конкурентной борьбы на мировом рынке высшего образования, чем инструментом управления профессиональным образованием в целом. Хотя для многих вузов попадание в мировые 
или национальные ранжированные списки является стимулом к развитию.

Вернемся к методике формирования рейтинга аграрных вузов Минсельхоза России. Агрегирование показателей и вычисление рейтинга производится поэтапно:

1. Формируется массив $\left[\mathrm{a}_{\mathrm{ij}}\right]$, размерностью $\mathrm{n} * \mathrm{~m}$, где $\mathrm{n}-$ число вузов, $\mathrm{m}$ - число показателей, $\mathrm{a}_{\mathrm{ij}}-$ значение j-го показателя для i-го вуза. Для обеспечения сопоставимости большинство показателей, включенных в массив, представляют собой относительные величины (например, в расчете на 100 человек научнопреподавательских работников (либо на одного работника), в расчете на приведенный контингент студентов, удельный вес в процентах).

2. Определяется максимальное значение для каждого показателя $\mathrm{a}_{\mathrm{maxj}}$.

3. Рассчитываются нормированные значения (рейтинговые баллы) показателей для каждого вуза:

$$
\mathrm{t}_{\mathrm{ij}}=\mathrm{a}_{\mathrm{ij}} / \mathrm{a}_{\operatorname{maxj}}
$$

По формуле (1) рассчитываются нормированные значения для всех показателей из массива $\left[\mathrm{a}_{\mathrm{ij}}\right]$ за исключением одного показателя - «Площадь земельных участков сельскохозяйственного назначения, вивариев, геодезических полигонов, учебно-опытных лесных участков (земель лесного фонда), га» (входит в группу показателей ФХД). Значение данного показателя нормируется в соответствии с таблицей 1 .

4. Для каждого вуза вычисляется средняя из нормированных значений (средний балл) по каждому направлению деятельности:

$$
\overline{b_{l}}=\frac{\sum_{1}^{k} t_{i j}}{k}
$$

где $k$ - количество показателей в группе по соответствующему направлению,

$l$ - число направлений деятельности (согласно методике, их 7).
5. Рейтинг аграрных вузов выстраивается относительно итогового рейтингового балла, рассчитываемого по формуле:

$$
\begin{aligned}
R_{i}= & \bar{b}_{\text {Од }}+\bar{b}_{\text {Нид }}+\bar{b}_{\text {Мд }}+\bar{b}_{\text {ФХд }} \\
& +\bar{b}_{\text {ВР }}+\bar{b}_{\text {ОП }}-\bar{b}_{\text {дп }}
\end{aligned}
$$

В конечном итоге перечень вузов упорядочивается по величине итогового рейтингового балла $\left(R_{i}\right)$ от максимального к минимальному (то есть лидером является вуз, набравший максимальный рейтинговый балл).

По результатам построения рейтинга вузы делятся на 3 группы:

1. Лидирующие вузы - $20 \%$ вузов, набравших наивысший суммарный балл.

2. Опорные аграрные вузы $-60 \%$ от общего числа вузов.

3. Вузы развития кадрового потенциала сельских территорий (вузы, требующие оптимизации деятельности) - 20\% вузов, набравших наименьший суммарный балл по всем оцениваемым направлениям деятельности.

Результаты исследования. Рассмотрим наиболее важные, на наш взгляд, показатели, достигнутые образовательными организациями (таблица 2).

По данным таблицы 2 можно сделать вывод, что в системе вузов Минсельхоза России занято 33,1 тыс. чел. (без учета совместителей), из них $38,1 \%$ - педагогические работники высшей школы, обучается по программам высшего образования 280.1 тыс. студентов, в том числе 15,5 тыс. иностранных студентов. В целом по всем вузам средний балл по итогам приемной компании 2019 г. сложился на уровне 59,17. При этом по программам высшего и послевузовского образования наблюдается снижение показателей, а по программам среднего профессионального образования - рост. Средняя численность штатных работников только за один год сократилась на 2051 чел., но доля преподавателей вузов в

Таблица 1. Порядок присвоения нормированного значения (рейтингового балла) по показателю «Площадь земельных участков сельскохозяйственного назначения, вивариев, геодезических полигонов, учебно-опытных лесных участков (земель лесного фонда), га»

\begin{tabular}{|l|c|}
\hline \multicolumn{1}{|c|}{$\begin{array}{c}\text { Площадь земельных участков } \\
\text { сельскохозяйственного назначения }\end{array}$} & Рейтинговый балл \\
\hline От 1 до 1000 & 1,0 \\
\hline От 1000 до 5000 & 1,1 \\
\hline От 5000 до 10000 & 1,2 \\
\hline Более 10000 & 1,3 \\
\hline
\end{tabular}


Таблица 2. Некоторые показатели, характеризующие масштабы деятельности аграрных вузов России (по итогам мониторинга за 2018 и 2019 гг.)

\begin{tabular}{|c|c|c|c|}
\hline Показатель & 2018 г. & 2019 г. & $\begin{array}{l}\text { Абсолютное измене- } \\
\text { ние } 2019 \text { г. к } 2018 \text { г. }\end{array}$ \\
\hline $\begin{array}{l}\text { Средняя численность работников списочного состава } \\
\text { (без внешних совместителей), чел. }\end{array}$ & 35194 & 33143 & -2051 \\
\hline $\begin{array}{l}\text { в том числе педагогические работники по программам } \\
\text { высшего образования }\end{array}$ & 13221 & 12634 & -587 \\
\hline Численность студентов ВО всего, чел. & 292875 & 280118 & -12757 \\
\hline Численность студентов СПО, чел. & 33126 & 34414 & 1288 \\
\hline Число принятых на программы ВО всего, чел. & 75591 & 73352 & -2239 \\
\hline Число принятых на программы СПО всего, чел. & 10611 & 11348 & 737 \\
\hline Выпуск студентов по программам ВО всего, чел. & 60736 & 61203 & 467 \\
\hline Выпуск студентов по программам СПО всего, чел. & 6922 & 7049 & 127 \\
\hline $\begin{array}{l}\text { Общее количество иностранных обучающихся в вузе } \\
\text { (по всем формам обучения по программам бакалавриа- } \\
\text { та, специалитета, магистратуры), чел. }\end{array}$ & 14610 & 15500 & 890 \\
\hline Численность аспирантов всего, чел. & 4735 & 4564 & -171 \\
\hline $\begin{array}{l}\text { Средний балл ЕГЭ студентов, принятых по результатам } \\
\text { ЕГЭ на обучение по очной форме по программам бака- } \\
\text { лавриата и специалитета }\end{array}$ & $\ldots$ & 59,17 & - \\
\hline
\end{tabular}

Источник: Департамент научно-технической политики и образования Министерства сельского хозяйства Российской Федерации.

Примечание: средний балл ЕГЭ студентов, принятых по результатам ЕГЭ на обучение по очной форме по программам бакалавриата и специалитета, начали рассчитывать с 2019 г.

общей численности работников, наоборот, повысилась с 38,6\% до 38,1\%, что свидетельствует о приоритетном сокращении вспомогательного и обслуживающего персонала.

По итогам 2019 г. сложилось следующее распределение аграрных вузов России в отраслевом рейтинге. В 1 и 3 группах включено по 11 вузов (по $20 \%$ от общего количества вузов), 32 вуза образовали группу опорных вузов. По сравнению с предыдущим годом в группе лидеров произошла небольшая ротация: из группы лидеров выбыл Брянский ГАУ, занявший 14 место в рейтинге по итогам 2019 г. (в 2018 г.- 11 место), в группу лидеров переместился Белгородский ГАУ, поднявшись с 12 на 10 место в рейтинге. В целом группа лидирующих вузов достаточно стабильна. В 2018 и 2019 гг. 1 и 2 места занимали ведущие аграрные университеты России - РГАУ-МСХА им. К.А. Тимирязева и Ставропольский ГАУ. Выше было отмечено, что эти университеты входят также в сотню лучших российских вузов [5].

Лидер рейтинга 2019 г. РГАУ-МСХА им. К.А.Тимирязева продемонстрировал высокие достижения по большинству оцениваемых показателей. Например, университетом достигнуты максимальные среди всех аграрных вузов значения таких показателей, как: «приведенный контингент», «количество научных журналов, включенных в перечень ВАК», «число диссертационных советов», «объем средств от образовательной деятельности, полученных от иностранных граждан и юридических лиц», «численность иностранных граждан, принятых по квоте». Итоговый рейтинговый балл Российского ГАУ составил 3,703. Отметим, что это значение выше минимального итогового рейтингового балла $(0,957$, РГАЗУ) в 3,8 раза.

В целом по всем аграрным вузам в 2019 г. по сравнению с 2018 г. 24 образовательные организации улучшили свои позиции в рейтинге. Отметим, вузы, сделавшие наиболее значительный рывок: Великолукская ГСХА (+14 позиций), Вятская ГСХА (+12 позиций), Мичуринский ГАУ, Ижевская ГСХА, Нижегородская ГСХА (каждая поднялась на 10 позиций в рейтинге). Существенно ухудшили свое положение в рейтинге Московская ГАВМ (-14 позиций), Костромская ГСХА (-12 позиций).

Выводы. Формирование рейтинга аграрных вузов - новая процедура управления системой высшего образования в Министерстве сельского хозяйства РФ. Как и любая система оценки, она с течением времени должна пересматриваться, совершенствоваться. Как инструмент управления, рейтинг вузов призван не только предо- 
ставлять информацию, но и направлять университеты в нужном направлении. Цифровизация экономики, возможности удаленного управления производственными процессами, быстрый обмен знаниями - это реалии современных общественных отношений, залог развития производства, в том числе в сельском хозяйстве и переработке сельхозпродукции. Принципы подготовки профессиональных кадров для АПК не могут не учитывать происходящие изменения. Следовательно, система показателей для комплексной рейтинговой оценки должна мотивировать руководителей аграрный вузов к развитию коллегиальности, сотрудничеству, расширению программы междисциплинарных исследований. На этом настаивают и зарубежные ученые, критически оценивающие современные рейтинги университетов.
Так, одним из новых подходов к формированию системы показателей является учет вклада университета в достижение Целей устойчивого развития, провозглашенных Организацией объединенных наций [8]. Возможно, в следующей редакции Порядка формирования рейтинга образовательных организаций высшего образования Минсельхоза России будет учитываться вклад вуза в достижение государственных целей в области устойчивого развития сельского хозяйства.

Таким образом, рейтинг аграрных вузов России является ценным инструментом управления развитием аграрного образования. Он позволяет выделить университеты-лидеры, сфокусироваться на основных проблемах отстающих вузов, а также определить приоритеты аграрного образования в нашей стране.

\section{Библиографический список}

1. Аграрные вузы должны работать в единой связке с бизнесом и наукой // Аграрная наука. 2020. № (7-8). С. $17-18$.

2. Воробьев А.Е. Глобальный или национальный рейтинг вузов? // Современные технологии управления. 2016. № 6 (66). С. $2-16$.

3. Постановление Правительства РФ «Об утверждении Федеральной научно-технической программы развития сельского хозяйства на 2017-2025 годы» от 25 августа 2017 г. № 996 [Электронный ресурс]. Доступ из справ.-правовой системы «КонсультантПлюс».

4. Приказ Министерства образования и науки Российской Федерации от 23 января 2018 г. № 41 «Об утверждении показателей эффективности деятельности федеральных бюджетных и автономных образовательных учреждений высшего образования и работы их руководителей, находящихся в ведении Министерства образования и науки Российской Федерации» [Электронный ресурс]. Доступ из справ.-правовой системы «КонсультантПлюс».

5. Рейтинг лучших вузов России RAEX-100 (2020 год) [Электронный ресурс] / https://raex-rr.com/education/ universities/rating_of_universities_of_russia (Дата обращения: 12.11.2020).

6. Рябчикова Н.Н. Перспективы развития аграрного образования в России: сотрудничество в рамках кластерно-сетевого подхода // Креативная экономика. 2020. Т. 14. № 4. С. 529-540.

7. Cadez S., Dimovski V., Zaman Groff M. Research, teaching and performance evaluation in academia: the salience of quality // Studies in Higher Education. 2017. Volume 42 (8), Pp. 1455-1473. DOI: 10.1080/03075079.2015.1104659.

8. Horta H., Santos J. M. Organisational factors and academic research agendas: an analysis of academics in the social sciences // Studies in Higher Education. 2019. Volume 45 (12), Pp. 2382-2397. DOI 10.1080/03075079.2019.1612351.

9. Uslu B. A path for ranking success: what does the expanded indicator-set of international university rankings suggest? // Higher Education. 2020. Volume 80, Issue 3, November 2020, Pp. 949-972. DOI: 10.1007/s10734-02000527-0. 